http://kitaibelia.unideb.hu/

ISSN 2064-4507 (Online) • ISSN 1219-9672 (Print)

(C) Department of Botany, University of Debrecen, Hungary

27(1): 123-125.; 2022

DOI: $10.17542 /$ kit.27.002

short communication • rövid közlemény

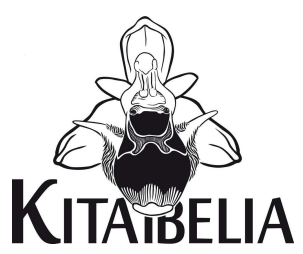

\title{
Szombathely város kámoni és herényi vízbázis- védőterülete, mint növényzeti értékek menedéke
}

\author{
BALOGH Lajos $^{1 *}$ \& SzINETÁr Csaba ${ }^{2}$
}

(1) Savaria Múzeum, Természettudományi Osztály, H-9700 Szombathely, Kisfaludy Sándor u. 9.; balogh.lajos@savariamuseum.hu

(2) ELTE Savaria Egyetemi Központ, Biológia Tanszék, H-9700 Szombathely, Károlyi Gáspár tér 4.

\section{The Kámon and Herény source water protection area in the city of Szombathely as a refuge for protected plant species}

\begin{abstract}
The hay meadows and protective forest strips of the Kámon and Herény source water protection areas in the northwestern part of Szombathely have been in good natural condition for decades. By harbouring populations of protected plant species (Anacamptis morio, Pyrola rotundifolia, Cephalanthera longifolia, Epipactis helleborine and Ophioglossum vulgatum), these areas resemble natural habitats found nearby in the Kőszeg Mountains and the Őrség National Park. The good seminatural condition can be attributed to the lack of regular mowing in the case of meadows and the lack of disturbance in the case of forest strips. In recent years, however, the area have been exposed to increasing human disturbance (car and motorcycle off-roading), so it may be timely to initiate legal protection. This short case study indicates that properly managed source water protection areas can play an important role in the conservation of semi-natural habitats, rare and protected plant species and the associated fauna.
\end{abstract}

Keywords: conservation, hay meadow, human disturbance, protected plant species, protective forest strip

Összefoglalás - A Szombathely északnyugati részén lévő kámoni és herényi vízbázis-védőterületek rétjei és erdősávjai évtizedek óta jó természetességi állapotúak. Botanikai értékeikkel szinte a Kőszegihegységet és az Örséget hozzák el a város határába. Ez a rétek esetében a rendszeres kaszálás, az erdősávok vonatkozásában pedig a bolygatás hiányának volt köszönhető. Olyan növényfajok kisebbnagyobb állományai fordulnak elő, mint például a Moenchia mantica, vagy a védett Anacamptis morio, Pyrola rotundifolia, Cephalanthera longifolia, Epipactis helleborine és Ophioglossum vulgatum. Az utóbbi években azonban egyes részeik egyre erősödő emberi zavarásnak (terepmotorozás, túragépkocsizás) vannak kitéve, ezért időszerű lehet védelmük kezdeményezése. E rövid esettanulmány is jelzi, hogy a megfelelően kezelt vízbázis-védőterületeknek fontos szerepe lehet természetközeli élőhelyek, ritka (esetenként védett) növényfajok (és a hozzájuk kapcsolódó állatvilág) térségjellemző képviselőinek, állományainak megőrzésében.

Kulcsszavak: emberi zavarás, kaszálórét, megőrzés, véderdősáv, védett növényfaj

Az alábbi, eddig jobbára kéziratosan rögzített, közel másfél évtized előtti állapotokat, a jelenben mások által folytatott újabb, a növényi értékek megóvását célzó vizsgálatokkal való öszszehasonlítás érdekében közöljük; az eset jellege miatt néhány növényelőfordulás kapcsán a napisajtóban megjelent adatra is hivatkozva. A két terület növényzeti értékeit az ezredforduló körüli években tárta fel részletesen a Közép-európai Flóratérképezés (KEF; KIRÁLY et al. 
2003, BARTHA et al. 2015) és a Magyarország Élőhelyeinek Térképi Adatbázisa (MÉTA; MoLNÁR et al. 2007) programok számára történt terepkutatás.

I) A kámoni vízbázis-védőterületen található fontosabb növényzeti értékek:

a) A Szombathely ÉNy-i határában, a Kámon és Olad városrész, illetve a Potyondi-mocsár és a Perint-patak közötti területet DK-ről és DNy-ról fekete nyárral (Populus nigra) és erdeifenyővel (Pinus sylvestris) nagyjából hat-hét évtizede telepített, mintegy 15 méter széles erdősáv határolta, amelyből 2007 tavaszán a kb. 10 méter széles nyarast levágták. A kevéssé szakszerű kitermelés következtében több helyütt a letermelni nem szándékozott külső, erdeifenyves sáv is erősen sérült, felszakadozottá vált. Ennek sajnos áldozatul esett a nyaras telepítése óta eltelt évtizedek során magától alátelepült alsó lombkorona- és cserjeszint is, amely az utóbbi időkre egyre javuló természetességi állapotba került és az alábbi fajokból állott (borítás szerinti sorrendben):

(a korábbi) alsó lombkoronaszint: Pinus sylvestris, Populus nigra, Populus tremula;

cserjeszint: Salix caprea, Pinus sylvestris, Populus tremula, Quercus robur, Cerasus avium, Cornus sanguinea, Hedera helix, Castanea sativa, Betula pendula, Crataegus monogyna, Rosa canina, Prunus spinosa, Padus avium, Rubus caesius, Carpinus betulus, Viburnum opulus, Juglans regia, Euonymus europaeus.

A mintegy 25 fajt számláló gyepszintben kb. tucatnyi foltban, ezen kívül itt-ott szálanként élt a védett kereklevelű körtike (Pyrola rotundifolia) kb. 500 töves állománya. Az élőhely 2007 tavaszi roncsoltsága, ágtörmelékkel való borítottsága miatt pontos tőszámlálásuk akadályba ütközött.

b) A területet DK-ről és DNy-ról határoló, 2007-ben levágott nyaras erdősávok találkozásának É-i oldali sarkában, a gyeppel való találkozás szegélyében legkevesebb 12 tő kardos madársisak (Cephalanthera longifolia) élt, amely a Kőszegi-hegységben, az Őrségben, a Vendvidéken és az Alsó-Kemenesháton (utóbbin helyenként) nem ritka, Vas megyében másutt azonban csak szórványosan előforduló növény. A növények 2007 tavaszán is bizonnyal virágoztak volna, de a fakitermelő munkálatok valószínűleg elroncsolták föld feletti hajtásaikat.

c) Az említett véderdősávok ölelésében, üde kaszálóréteken tengernyi rigószegfú (Moenchia mantica) és szórványosan agár-sisakoskosbor (Anacamptis morio) élt. A rigószegfú nem védett, de nem is gyakori virág e vidéken.

II) A herényi vízbázis-védőterületen található fontosabb növényzeti értékek:

A Szombathely északnyugati határában, a Herény és Olad városrész, illetve a Potyondiárok és a Perint-patak közötti, hasonló véderdősávok határolta élőhelyen üde és mezofil kaszálórétek, sztyepprét-jellegű foltok terülnek el, 2007-ben a kámoninál valamivel kevesebb rigószegfűvel (Moenchia mantica), de sokkal több, mintegy ezres nagyságrendben előforduló agár-sisakoskosborral (Anacamptis morio).

III) A két vízbázis-védőterület növényzeti értékeiről 2007 tavaszán az illetékes - természetvédelmi és környezetvédelmi - szakmai és hatósági szerveket is értesítettük, illetve bejártuk képviselőikkel. Az azóta előkerült további ritka, védett növények (pl. széleslevelű nőszőfü, Epipactis helleborine) florisztikai adatait a hazai flóraatlasz nyomtatott (BARTHA et al. 2015), majd világhálós adatbázisa (BARTHA et al. 2021) számára is eljuttattuk, vagy a flóraatlaszt kiegészítő cikkben közöltük, például Ophioglossum vulgatum a kámoni vízbázisterületen (BALOGH in MoLNÁR et al. 2018); fenológiai érdekességként jegyezzük meg, hogy a kígyónyelvharasztok zöme 2021. május 26-án majdnem kifejlett sporofillumfüzéres, ellentétben a megtalálás idejével (2016. június 6.), amikor túlnyomó többségük meddő volt.

E jó természetességi állapotú, városperemi vízbázis-védőterületek (rétek és véderdősávjaik) ilyetén ismeretét eddig azért nem hoztuk a nagyközönség előtti nyilvánosságra, mert tartottunk a (szombat)helyi kirándulók esetleges érdeklődésétől. Védettségüket pedig még azért nem kezdeményeztük, mert kezelőjük, a Vas megyei Víz- és Csatornamű Vállalat jó 
gazdájuknak bizonyult, hiszen rétjeik természetvédelmi szempontból is kedvező állapotának fenntartását a megfelelő időszakokban végzett kaszálásokkal biztosították.

IV) 2021 tavaszán Varga Tamás, a közeli, kámoni Gothard Jenő Általános Iskola biológiatanára és nyolcadikos tanítványai is rátaláltak a kámoni vízbázis-védőterület értékes élőhelyére, ahol újabb védett növényfaj, a békakonty (Listera ovata) közel száz töves állománya is előkerült (SaFó 2021). Mivel a bekerítetlen részeken az utóbbi időkben megélénkült a terület értékes élővilágát veszélyeztető, a gyomosodást elősegítő, engedély nélküli terepmotorozás és túragépkocsizás, már indokoltan merül fel a védetté nyilvánítás szükségessége. Első lépésként a terület kezelője a kámoni vízbázis-védőterület kaszálórétjének autós megközelítését lehetővé tevő dűlőutat 2021 májusában sorompóval lezárta (SaFó 2021), az iskola, tanára és diákjai pedig az orchideás rét örökbefogadását tervezik. A 2021. évi fejleményekről először tudósító cikk (GYöNGYössY 2021) meglátása tudományosan is helytálló: „botanikai értékeivel a Kőszegi-hegységet és az Őrséget hozza el a közvetlen szomszédunkba" Szombathely határába.

V) E rövid esettanulmány is jelzi, hogy a megfelelően kezelt vízbázis-védőterületeknek milyen fontos szerepe lehet értékes, természetközeli élőhelyek, ritka (esetenként védett) növényfajok (és a hozzájuk kapcsolódó állatvilág) megmaradásában. A kutatóknak, természetvédelmi szakembereknek és hatóságoknak is érdemes lenne rendszeres, országos kutatás tárgyává tenni, illetve óvó figyelemmel kísérni e területeket, mint az élővilág kevéssé ismert, mesterséges elzártság rejtette, lappangó menedékhelyeit.

\section{Irodalom}

BARTHA D., BÁN M., SChmidT D. \& TiBorcz V. (2021): Magyarország edényes növényfajainak online adatbázisa. - Soproni Egyetem, Erdőmérnöki Kar, Növénytani és Természetvédelmi Intézet, Sopron, http://floraatlasz.uni-sopron.hu (hozzáférés: 2021. 06. 22.)

Bartha D., Király G., Schmidt D., Tiborcz V., Barina Z., Csiky J., Jakab G., Lesku B., Schmotzer A., Vidéki R., Vojткó A. \& Zólyomi Sz. (szerk.) (2015): Magyarország edényes növényfajainak elterjedési atlasza. Nyugat-Magyarországi Egyetem Kiadó, Sopron, 329 pp.

GY[ÖNGYÖSSY] P. (2021): Ezer tő orchidea. Védetté nyilváníttatnák a virágos rétet. - Vas Népe 66(101): 16 (máj. 4.).

Király G., Balogh L., Barina Z., Bartha D., Bauer N., Bodonczi L., Dancza I., Farkas S., Galambos I., Gulyás G., Molnár V. A., Nagy J., Pifkó D., Schmotzer A., Somlyay L., Szmorad F., Vidéki R., VojtKó A. \& Zólyomi Sz. (2003): A magyarországi flóratérképezés módszertani alapjai. Útmutató és magyarázat a hálótérképezési adatlapok használatához. - Flora Pannonica 1(1): 3-20.

Molnár Cs., Haszonits Gy., Malatinszky Á., Süveges K., Balogh L., Nagy T., Horváth S. \& Hudák K. (2018): Pótlások Magyarország edényes növényfajainak elterjedési atlaszához VI. - Kitaibelia 23(1): 87-102.

Molnár Zs., Bartha S., Seregélyes T., Illyés E., Botta-DukÁt Z., TímÁr G., Horváth F., Révész A., Kun A.,

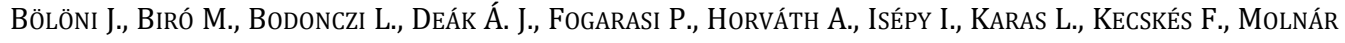
Cs., ORTMANN-NÉ AJKAI A. \& RÉv Sz. (2007): A grid-based, satellite-image supported multi-attributed vegetation mapping method (MÉTA). - Folia Geobotanica 42: 225-247.

SaFó (2021): A védett orchideák rétje a város szélén. - Savaria Fórum 30(19): 8.

Beérkezett / received: 2021. 06. 25. • Elfogadva / accepted: 2021. 09.14. 